\title{
Spruce Plywood Bonding
}

Milan Brožek

Czech University of Life Sciences Prague. 16521 Praha 6 - Suchdol, Czech Republic, Phone: +420 22438 3265, E-mail: brozek@tf.czu.cz

The contribution contains results of bonded joints strength tests. The tests were carried out according to the modified standard CSN EN 1465 (66 8510). For bonding the spruce three-ply wood of $4 \mathrm{~mm}$ thickness was used (according to CSN EN 636). The test samples of $100 \times 25 \mathrm{~mm}$ size were cut out from a semi-product of $2440 \times 1220$ $\mathrm{mm}$ size in the direction of its longer side (angle $0^{\circ}$ ), in the oblique direction (angle $45^{\circ}$ ) and in the direction of its shorter side (crosswise - angle $\mathbf{9 0}^{\circ}$ ). The bonding was carried out using eight different domestic as well as foreign adhesives according to the technology prescribed by the producer. All used adhesives were designated for wood bonding. At the bonding the consumption of the adhesive was determined. After curing the bonded assemblies were loaded using a universal tensile-strength testing machine up to the rupture. The rupture force and the rupture type were registered. Finally the technical-economical evaluation of the experiments was carried out.

Keywords: bonding, adhesive, bonded joints testing, costs of bonding

\section{Acknowledgement}

Supported by the Internal Grant Agency of the Czech University of Life Sciences Prague, Prague, Czech Republic; Project No. 2014:31140/1312/3133.

\section{References}

[1] BROŽEK, M. (2013). Technical-economical evaluation of plywood bonding. In.: $5^{\text {th }}$ International Conference Trends in Agricultural Engineering, pp. 100-105. Czech University of Life Sciences Prague, Prague, Czech Republic.

[2] BROŽEK, M. (2014). Technical-economical evaluation of beech plywood bonding. In.: $13^{\text {th }}$ International Scientific Conference Engineering for Rural Development, pp. 168-173. Latvia University of Agriculture, Jelgava, Latvia.

[3] BROŽEK, M. (2013). Optimization of adhesive layer thickness at metal bonding using quick-setting adhesives. Manufacturing Technology. Vol. 13, No. 4, pp. 419-423.

[4] BROŽEK, M. (2013). Soldering steel sheets using soft solder. Research in Agriculture Engineering. Vol. 59, No. 4, pp. 141-146.

[5] BROŽEK, M. (2013). Soldering sheets using soft solders. Acta Universitatis Agriculturae et Silviculturae Mendelianae Brunensis. Vol. 61, No. 6, pp. 1597-1604.

[6] BROŽEK, M. (2012). Wear resistance of multi-layer overlays. In.: $11^{\text {th }}$ International Scientific Conference Engineering for Rural Development, pp. 210-215. Latvia University of Agriculture, Jelgava, Latvia.

[7] BROŽEK, M. (2011). Layer number influence on weld deposit chemical composition. In.: $10^{\text {th }}$ International Scientific Conference Engineering for Rural Development, pp. 393-397. Latvia University of Agriculture, Jelgava, Latvia.

[8] CAGLE, CH. V. (1973). Handbook of adhesive bonding. New York, Mac-Graw-Hill.

[9] CHEN, C. M. (1995). Gluability of Kraft Lignin Copolymer Resins on Bonding Southern Pine Plywood. Holzforschung, Vol. 49, No. 2, pp. 153-157.

[10] CHENG, R.-X., WANG, Q.-W. (2011). The Influence of FRW-1 Fire Retardant Treatment on the Bonding of Plywood. Journal of Adhesion Science and Technology, Vol. 25, No. 14, pp. 1715-1724.

[11] EBNESAJJAD, S. (2008). Adhesives technology handbook. $2^{\text {nd }}$ Ed., 363 p., William Andrew, Norwich.

[12] EPSTEIN, G. (1954). Adhesive bonding of metals. 218 p. Reinhold, New York, USA.

[13] FAN, D. B., QIN, T. F., CHU, F. X. (2011). A new interior plywood adhesive based on oil-tea cake. Advanced Materials Research, Vol. 194-196, pp. 2183-2186.

[14] GARCIA ESTEBAN, L., GARCIA FERNANDEZ, F., DE PALACIOS, P. (2011). Prediction of Plywood Bonding Quality Using an Artificial Neural Network. Holzforschung, Vol. 65, No. 2, pp. 209-214. 
[15] HE, G., FENG, M., DAI, C. (2012). Development of soy-based adhesives for the manufacture of wood composite products. Holzforschung. Vol. 66, No. 7, pp. 857-862.

[16] LOCTITE EUROPEAN GROUP (1988). Worldwide Design Handbook. $2^{\text {nd }}$ Ed., 452 p., Loctite European Group, München.

[17] NOVÁKOVÁ, A., BROŽEK, M. (2009). Bonding of non-metallic materials using thermoplastic adhesives. In.: $8^{\text {th }}$ International Scientific Conference Engineering for Rural Development, pp. 261-264. Latvia University of Agriculture, Jelgava, Latvia.

[18] OLIVARES, M., Slellers, T. (1994). Resin-adhesive Formulations for Bonding Exterior-type Plywood Using Chilean Radiata Pine and 4 Hardwoods. Holzforschung. Vol. 48, No. 2, pp. 157-162.

[19] PIZZI, A., MITTAL, K. L. (2003). Handbook of adhesive technology. $2^{\text {nd }}$ rev. and expanded ed., 1024 p. Dekker, New York.

[20] SELLERS, T (1989). Diisocyanate Furfural Adhesive for Bonding Plywood. Forest Production Journal. Vol. 39, No. 11-12, pp. 53-56.

[21] YANG, I., KUO, M., MYERS, D. J. (2006). Bond Quality of Soy-based Phenolic Adhesives in Southern Pine Plywood. Journal of the American Oil Chemists' Society. Vol. 73, No. 3, pp. 231-237.

[22] ČSN EN 636 (49 2419), 2013. Překližované desky - Požadavky (Plywood - Specification). Český normalizační institut, Praha.

ČSN EN 1465 (66 8510), 2009. Lepidla - Stanovení pevnosti ve smyku při tahovém namáhání přeplátovaných lepených sestav (Adhesives - Determination of tensile lap-shear strength of bonded assemblies). Český normalizační institut, Praha. 